Zeszyty Naukowe Szkoły Głównej Gospodarstwa Wiejskiego w Warszawie

Problemy Rolnictwa Światowego tom 19 (XXXIV), zeszyt 3, 2019:67-74

DOI: 10.22630/PRS.2019.19.3.47

Edyta Lyżwa $^{1}$

Uniwersytet Jana Kochanowskiego w Kielcach

\title{
Inwestycje jako determinanta rozwoju sektora rolnego na Ukrainie
}

\section{Investments as a Determinant of the Agricultural Sector Development in Ukraine}

\begin{abstract}
Synopsis. Znaczenie badań nad gospodarką rolną Ukrainy ma kluczowe znaczenie w perspektywie bezpieczeństwa żywnościowego kraju i Europy. W artykule przyjęto inwestycje jako podstawowa determinantę rozwoju sektora. Tłem rozważań są przemiany sektora rolnego po odzyskaniu niepodległości przez Ukrainę. Zakresem badań objęto terytorium Ukrainy przywołując dane empiryczne z lat 1991-2018 ze szczególnym uwzględnieniem zakresu procesów inwestycyjnych w latach 2012-2018. Celem artykułu było zidentyfikowanie aktywności inwestycyjnej we współczesnej gospodarce rolnej Ukrainy. Przywołane dane pozwalają na wyciąniecie wniosków o nieefektywnym wykorzystaniu potencjału rolnictwa i przetwórstwa rolno-spożywczego w skali kraju oraz intensyfikacji aktywności inwestycyjnej państwa w ostatnich latach wspierających rozwój tego sektora gospodarki.
\end{abstract}

Slowa kluczowe: sektor rolno-spożywczy, rozwój, inwestycje, gospodarka Ukrainy

\begin{abstract}
The importance of researching the agricultural economy of Ukraine have got big importance in the perspective of the country's and Europe food security. The article accepts investments as the basic determinant of the sector's development. The background of the reflections is the transformation of the agricultural sector after Ukraine regained it's independence. The research covered territory of Ukraine, recalling empirical data from the years 1991-2018, with particular emphasis of the investments in 20122018. The purpose of the article was to identify investment activity in the modern agricultural Ukraine's economy. The mentioned data allowed us to draw conclusions about the ineffective use of the country's agriculture potential and agri-food processing as well as the intensification of the state's investment activity in recent years that support the development of this sector's economy.
\end{abstract}

Key words: agri-food sector, development, investments, economy of Ukraine

JEL Classification: E22, F43, O52, R58

\section{Wprowadzenie}

Ukraina dysponuje największa, po Rosji, powierzchnią użytków rolnych w Europie (około $70 \%$ powierzchni państwa). Dzięki dogodnemu klimatowi i urodzajności gleb (czarnoziemy o najwyższej klasie żyzności) Ukraina ma bardzo dogodne warunki dla upraw i jest jednym z czołowych producentów zbóż w Europie. Rolnictwo Ukrainy ma obecnie, wg danych rządowych, ponad $17 \%$ udziału w produkcie krajowym brutto a o jego znaczeniu decyduje przede wszystkim produkcja roślinna.

\footnotetext{
${ }^{1}$ dr, Instytut Prawa, Ekonomii i Administracji, UJK Kielce, ul. Świętokrzyska 21A, 25-406 Kielce, e-mail: edyta.lyzwa@ujk.edu.pl; https://orcid.org/0000-0001-5853-9963
} 
Badania nad gospodarką rolną kraju mają kluczowe znaczenie w perspektywie bezpieczeństwa żywnościowego Ukrainy i Europy. W artykule przyjęto inwestycje jako podstawową determinantę rozwoju sektora poddając obserwacji przykłady aktywności w tym zakresie $\mathrm{w}$ ostatnich latach. Tłem rozważań są przemiany sektora rolnego po odzyskaniu niepodległości przez Ukrainę. Zakresem badań objęto terytorium Ukrainy przywołując dane empiryczne $\mathrm{z}$ lat 1991-2018 ze szczególnym uwzględnieniem zakresu procesów inwestycyjnych w latach 2012-2018. Celem artykułu było zidentyfikowanie aktywności inwestycyjnej we współczesnej gospodarce rolnej Ukrainy. Przywołane zdarzenia gospodarcze i dane statystyczne pozwalają na wyciagniecie wniosków o intensyfikacji aktywności inwestycyjnej w ten sektor gospodarki Ukrainy. Uzyskane wyniki mogą przyczynić się do rozwoju wiedzy na temat sektora rolnego Ukrainy i współczesnych przemian w nim zachodzących, warunkowanych, m. in., specyficzną historią rozwoju sektora.

W artykule wyróżniono dwie zasadnicze części: pierwszą, której treść nawiązuje do przekształceń sektora rolnego na Ukrainie w ujęciu historycznym oraz drugą, zorientowaną na wskazanie elementów współczesnej polityki inwestycyjnej. Szczególnie pomocne w opracowaniu materiału były: w części pierwszej - publikacja Arkadiusza Sarny pt. Transformacja ukraińskiego rolnictwa: od kołchozów do agroholdingów, w części drugiej - artykuły i analizy publikowane na łamach portalu rolniczego Farmer.pl. Dobór źródeł informacji umożliwił całościowe spojrzenie na specyfikę sektora od 1991 roku oraz wykorzystanie bardzo aktualnych danych opisujących stan obecny.

\section{Przekształcenia sektora rolnego na przełomie XX i XXI wieku}

Po uzyskaniu niepodległości przez Ukrainę nastąił długotrwały kryzys w rolnictwie spowodowany załamaniem się dotychczasowej gospodarki centralnie planowanej i niedostosowaniem sektora do nowych realiów ekonomicznych. Brak odpowiednich doświadczeń rynkowych, kapitału na inwestycje i spójnej wizji elit rządzących o docelowym modelu transformacji utrudniał przekształcenia. Za jeden $\mathrm{z}$ głównych celów transformacji gospodarki rolnej uznano jednak powszechną bezpłatną prywatyzację ziemi, skutkiem czego w latach 90. XX wieku zlikwidowano niemal wszystkie kołchozy (12 tys.). Ich majątek przekazano w kolektywną własność nowo utworzonym, niepaństwowym przedsiębiorstwom. Pracownicy byłych kołchozów w większości utrzymali zatrudnienie w tych nowych podmiotach. Przyznano im prawo do równego udziału w ziemi przedsiębiorstw - tzw. paju (pai - działki o rozmiarze od 2 do 5 ha.; zwykle około 4 ha). Nie oznaczało to jednak automatycznie prawa do udziału w ziemi w naturze w konkretnej lokalizacji i wydania aktów własności ziemi. Sytuację uporządkowała dopiero ustawa $\mathrm{z}$ maja 2003 roku, w wyniku której do końca 2012 roku ponad 70\% użytków rolnych znalazło się we własności prywatnej a akty własności wydano ponad $90 . \%$. uprawnionych. Część mieszkańców wsi uzyskała ponadto na własność, z zasobów państwowych bądź komunalnych, niewielkie działki (średnio w skali kraju: poniżej 0,4 ha) dla prowadzenia przydomowych indywidualnych gospodarstw rolnych, które dla wielu mieszkańców wsi okazały się podstawą utrzymania. Zwieńczeniem procesu miało być uruchomienie swobodnego rynku ziemi. Zamiast tego wprowadzano kolejne memoranda na obrót ziemią rolną (obowiązujące od 2001 roku; ostatnie przedłużenie do 1 stycznia 2020 roku) dając czas na stworzenie odpowiednich warunków umożliwiających funkcjonowanie rynku 
(stworzenie niezbędnej infrastruktury prawno-instytucjonalnej), podtrzymując tym samym podstawy rozwoju gospodarki rolnej opierające się na dzierżawie ziemi (Sarna, 2014). „Farmerzy na Ukrainie nie mają zatem prywatnej ziemi - muszą ją wynajmować od właścicieli. Duże gospodarstwa potrafią wynajmować w taki sposób nawet 400 tys. ha. Średnie gospodarstwa uprawiają od 2 do 6 tys. ha, natomiast gospodarstwa liczące setki hektarów uważane są za drobne. Osoby uprawiające 20,30, 40 ha postrzegane są jako $<<$ aktywni rolnicy $>>$, ale nie farmerzy." (Pawljuk, 2017)

Jak już zauważono, prywatyzacja ziemi bez prawa w pełni swobodnego nią dysponowania przyczyniła się do rozwoju gospodarki rolnej w oparciu o dzierżawę gruntów (sprzyjało temu ustawowe dopuszczenie wykorzystania paju jako przedmiotu dzierżawy). Niskie koszty dzierżawy, opłacane często w formie towarów i usług, pobudzały rozwój prywatnych, dużych przedsiębiorstw rolnych. Ponadto, wprowadzenie ustawą $z$ grudnia 1998 roku tzw. stałego podatku rolnego, ulgi w podatku VAT, państwowych dotacji na produkcję rolną wraz z coraz atrakcyjniejszymi warunkami eksportu sprzyjały rozwojowi wielkoobszarowych gospodarstw. W ostatnich latach przyspieszył proces konsolidacji spółek rolnych prowokując powstawanie tzw. agroholdingów (Tabela 1.), kontrolowanych głównie przez kapitał ukraiński. Ich działalność sprowadza się do ekstensywnego modelu gospodarowania - maksymalnego wykorzystania zasobów w okresie obowiązywania umów dzierżawy a w konsekwencji degradacji ziem i dewastacji wykorzystywanych zasobów (Sarna, 2014).

Tabela 1. Największe agroholdingi Ukrainy

Table 1. The largest agroholdings of Ukraine

\begin{tabular}{|c|c|c|c|c|}
\hline & Nazwa/ skrócona nazwa & $\begin{array}{l}\text { Właściciel/ } \\
\text { główny akcjonariusz }\end{array}$ & $\begin{array}{l}\text { Bank ziemi } \\
\text { (w tys. ha) }\end{array}$ & Główny profil działalności \\
\hline 1. & Ukrlandfarming & Ołeh Bachmatiuk & 670 & $\begin{array}{l}\text { Produkcja i eksport zbóż, mięsa, } \\
\text { jaj i produktów jajecznych, mleka }\end{array}$ \\
\hline 2. & Grupa Kernel & Andrij Werewski & 422 & $\begin{array}{c}\text { Produkcja i eksport zbóż, oleju } \\
\text { słonecznikowego }\end{array}$ \\
\hline 3. & $\mathrm{NCH}$ & $\begin{array}{l}\text { George Rohr, } \\
\text { Moris Tabacinic }\end{array}$ & 400 & $\begin{array}{c}\text { Produkcja zbóż, słonecznika, soi, } \\
\text { hodowla zwierzęca }\end{array}$ \\
\hline 4. & $\begin{array}{l}\text { Mironowśki } \\
\text { Chliboprodukt }\end{array}$ & Jurij Kosiuk & 320 & $\begin{array}{c}\text { Hodowla drobiu, produkcja zbóż, } \\
\text { wyrobów mięsnych }\end{array}$ \\
\hline 5. & Mrija Agroholding & Iwan Huta & 298 & $\begin{array}{l}\text { Produkcja zbóż, buraków } \\
\text { cukrowych, ziemniaków }\end{array}$ \\
\hline 6. & $\begin{array}{l}\text { Ukraińskie Agrarne } \\
\text { Inwestycii }\end{array}$ & Renesans Group & 261 & Produkcja i eksport zbóż \\
\hline 7. & Astarta & Wiktor Iwanczyk & 245 & Produkcja cukru, zbóż, mleka \\
\hline 8. & HarvEast & $\begin{array}{l}\text { Rinat Achmetow } \\
\text { (i Wadym Nowiński) }\end{array}$ & 197 & $\begin{array}{l}\text { Produkcja zbóż, pasz, nasion, } \\
\text { mleczarstwo }\end{array}$ \\
\hline 9. & Agroton & Jurij Żurawlow & 151 & $\begin{array}{l}\text { Produkcja słonecznika, pszenicy, } \\
\text { spożywcza, hodowla }\end{array}$ \\
\hline 10. & Sintal Agriculture & Mykoła Tołmaczew & 150 & Produkcja zbóż i cukru \\
\hline
\end{tabular}

Źródło: Sarna, 2014 za: Latifundist.com ; coroczna aktualizacja danych największych agroholdingów „Top 100 Latifundists Ukrainy" dostępna w: https://latifundist.com/rating/top100\#. 
Brak swobodnego rynku ziemi i ograniczenia w nabywaniu gruntów rolnych skutkują tym, że inwestorzy zagraniczni działają głównie w obszarze przetwórstwa rolnego i w handlu ukraińskim zbożem lub, w sposób pasywny, poprzez inwestycje w akcje ukraińskich spółek rolnych notowanych za granicą Ukrainy. Wzrost inwestycji w sektorze jest jednak hamowany nie tylko przez inwestorów zagranicznych ale także przez rodzimych właścicieli przedsiębiorstw, którzy są uzależnieni od horyzontu inwestycyjnego, ograniczonego do okresu obowiązywania umów dzierżawnych (Sarna, 2014). Do uwolnienia obrotu gruntami rolnymi zachęcał przedstawiciel Międzynarodowego Funduszu Walutowego (MFW) na Ukrainie Goesta Ljungman, który mówił: „Brak rynku obrotu ziemią nie sprzyja rozwojowi gospodarki i nie pozwala na napływ inwestycji zagranicznych". Zdaniem deputowanego frakcji "Swoboda" Jurij Łewczenki niepokojące jest jednak to, że: „Dzisiaj 60 procent Ukraińców żyje poniżej granicy ubóstwa. Kto kupi tę ziemię? Tylko oligarchowie.” (Parlament..., 2017) „Większość posłów uważała, że zniesienie moratorium (...) stanowi zagrożenie dla krajowego bezpieczeństwa żywnościowego oraz, że, przed liberalizacją rynku ziemi, należy opracować mechanizm zwiększania przejrzystości w zakresie obrotu gruntami rolnymi. Ponadto, przed otwarciem obrotu ziemią, konieczne byłoby stworzenie równych szans na rynku oraz jasne określenie odpowiedzialność każdego organu podczas wprowadzania reformy rolnej i inwentaryzacji gruntów rolnych. Według Banku Światowego moratorium jest główną przeszkodą dla inwestycji i źródłem słabej wydajności rolnictwa.” (Grunty..., 2017)

\section{Elementy polityki inwestycyjnej państwa w latach 2012-2018}

Wybrane wskaźniki rozwoju sektora rolnego na Ukrainie, na tle innych państw mających znaczny wkład rolnictwa w UE lub na świecie, przedstawiono w Tabeli 2. Zwraca uwagę udział ludności rolniczej w ogóle ludności (prawie 31\%) oraz ponad 56\% powierzchni użytków rolnych kraju stanowiących grunty orne. Wskaźnik na mieszkańca gruntów ornych jest najwyższy wśród wyszczególnionych państw Europy i niższy (w grupie przywołanych gospodarek) jedynie wobec gospodarki kanadyjskiej. Równocześnie jednak plony zbóż z jednego ha są najniższe w porównaniu do przywołanych przykładów gospodarek innych krajów. Uzysk mięsa oraz udój mleka są również kategoriami o niższej efektywności niż w innych, wskazanych w Tabeli 2., gospodarkach.

Z inicjatywy naukowców w 2013 roku został opracowany projekt „Strategia rozwoju rolniczo-przemysłowego kompleksu Ukrainy” (Стратегія..., 2013) jako podstawowy rządowy dokument strategiczny. Autorzy wyszli z założenia, że produkcja rolniczoprzemysłowa jest składową jednego narodowo-gospodarczego kompleksu a branże przemysłowe (w tym produkcja maszyn czy produkcja chemiczna) kluczowe dla produkcji, przechowywania, przerobu i realizacji przygotowanej do konsumpcji produkcji. Celem Strategii jest zabezpieczenie stabilnego i efektywnego funkcjonowania sektora rolnoprzemysłowego, zorientowanego na zaspokojenie wewnętrznych i eksportowych potrzeb kraju $\mathrm{w}$ produkcji gospodarki rolnej $\mathrm{w}$ prognozowanym okresie. To także socjalne odrodzenie wsi, przezwyciężenie ubóstwa przeważającej części rolników i innych jego mieszkańców oraz stopniowe zbliżenie warunków ich życia i pracy do poziomu ekonomicznego rozwiniętych krajów. Realizacja zadań wynikających ze Strategii ma umożliwić, m. in., radykalne zwiększenie, w tym dla celów agrarnych, państwowych i niepaństwowych inwestycji, podwyższanie efektywności ich użycia (ekonomicznej, 
ekologicznej, społecznej) oraz aktywizację inwestycyjną producentów wszystkich form własności i gospodarowania (Gutkewicz i Sydorenko, 2016).

Tabela 2. Wskaźniki rozwoju sektora rolnego na Ukrainie oraz w państwach o znacznym wkładzie rolnictwa na świcie lub UE w 2012 roku

Table 2. Indicators of agricultural sector development in Ukraine and in countries with significant agricultural input in the world or in the EU in 2012

\begin{tabular}{|c|c|c|c|c|c|c|}
\hline \multirow{2}{*}{ Wyszczególnienie } & \multicolumn{6}{|c|}{ Wybrane państwa } \\
\hline & Ukraina & Polska & Niemcy & Francja & Kanada & USA \\
\hline $\begin{array}{l}\text { Ludność rolnicza (\% ogółu } \\
\text { ludności) }\end{array}$ & 30,9 & 39,2 & 25,9 & 13,6 & 19,2 & 17,4 \\
\hline $\begin{array}{l}\text { Ludność aktywna } \\
\text { zawodowo w rolnictwie (\% } \\
\text { ogółu ludności) }\end{array}$ & 5,0 & 7,3 & 0,7 & 0,8 & 0,9 & 0,8 \\
\hline Użytki rolne (mln ha) & 41,3 & 14,5 & 16,7 & 28,8 & 65,3 & 408,7 \\
\hline Grunty orne (mln ha) & 32,5 & 10,9 & 11,8 & 18,3 & 45,3 & 155,1 \\
\hline - w \% powierzchni & 56,1 & 35,7 & 34,0 & 33,4 & 5,0 & 17,0 \\
\hline - na 1 mieszkańca, ha & 0,7 & 0,3 & 0,1 & 0,3 & 1,4 & 0,5 \\
\hline Plony zbóż z 1 ha (dt) & 31,7 & 37,0 & 69,0 & 75,2 & 36,2 & 59,2 \\
\hline $\begin{array}{l}\text { Uzysk mięsa od } 1 \text { sztuki } \\
\text { bydła }(\mathrm{kg} / \mathrm{rok})\end{array}$ & 152 & 247 & 314 & 302 & 385 & 350 \\
\hline $\begin{array}{l}\text { Udój mleka od } 1 \text { krowy } \\
\text { (kg/rok) }\end{array}$ & 4431 & 4991 & 7280 & 6583 & 8817 & 9841 \\
\hline
\end{tabular}

Źródło: Główny Urząd Statystyczny.

Według ukraińskiego ministerstwa rolnictwa od stycznia do września $2017 \mathrm{r}$. zainwestowano $\mathrm{W}$ sektor kwoty znacznie przekraczające inwestycje $\mathrm{z}$ roku poprzedzającego. Inwestycje w rolnictwo, łowiectwo i usługi powiązane wzrosły o $37,8 \%$, inwestycje kapitałowe $\mathrm{w}$ rolnictwie o $15,6 \%$ a inwestycje kapitałowe w produkcje artykułów spożywczych, napojów i wyrobów tytoniowych o 7,5\%. Głównym źródłem finansowania inwestycji kapitałowych pozostawały środki własne przedsiębiorstw i organizacji produkcyjnych. Udział inwestycji kapitałowych w przetwórstwo żywności wyniósł 14,6\% całkowitej wielkości inwestycji w przemyśle. Od 1 lipca 2017 r. w sektorze rolnym realizowane były 233 projekty inwestycyjne (łączny koszt około 36,7 mld hrywien) (Ukraina zainwestowała..., 2018).

Planowanemu zwiększeniu udziału rolnictwa w PKB mają służyć programy pomocy państwa. Wysokość wsparcia w 2018 roku miała wynieść 6,3 mld. hrywien (przy 5,5 mld w 2017 roku). Rząd ukraiński dążył do rozwoju produkcji zwierzęcej, ruchu spółdzielczego, wsparcia dla ogrodnictwa i produkcji ukraińskich maszyn rolniczych (Rząd..., 2018).

Wśród priorytetów są programy koncentrujące się na branżach, które mogą zapewnić długofalowy efekt ekonomiczny. W 2018 roku zaproponowane były programy wsparcia rolnictwa (Rząd..., 2018) obejmujące takie obszary jak:

- kompensacja 25\% kosztów nabycia nowych maszyn rolniczych i sprzętu produkcji ukraińskiej,

- rekompensaty pożyczki zaangażowanej $\mathrm{w}$ budowę kompleksów dla zwierząt gospodarskich, która stanowi efektywną stawkę na poziomie 3\%, zwrot kosztów 
oddanych do użytku kompleksów inwentarskich zbudowanych na własny koszt inwestora, a także obniżenie do $3 \%$ ceny pożyczek na projekty realizowane $\mathrm{w}$ dziedzinie akwakultury, hodowli owiec, uprawy owoców jagodowych itp.,

- obniżenie kosztów utrzymania bydła w przedsiębiorstwie rolnym w wysokości 1,5 tys. hrywien na zwierzę na rok,

- zmniejszenie kosztów utrzymania młodych zwierząt (do 1 roku), które trzymane są w gospodarstwach domowych w wysokości 2,5 hrywien na zwierzę na rok,

- zmniejszenie o 80 proc. kosztów materiału szkółkarskiego w ogrodnictwie i sadzonek owoców jagodowych,

- zapewnienie małym i średnim gospodarstwom zwrotu 100.\% kosztów zakupu ukraińskich nasion i 90.\% kosztów usług doradczych oraz objęcie tych producentów rolnych dostępem do tanich kredytów i dodatkowych preferencji przy zakupie ukraińskich maszyn rolniczych (rekompensata w wysokości 40.\% wartości),

- $\quad$ w ramach wsparcia i rozwoju spółdzielni usług rolniczych państwo będzie współfinansować projekty realizowane w zakresie hodowli zwierząt, ogrodnictwa, budowy magazynów warzyw i owoców oraz ponosić $70 \%$ kosztów zakupu nowego sprzętu dla nich.

Interesującym przykładem wsparcia państwa $\mathrm{w}$ procesach inwestycyjnych jest uruchomienie rządowego programu wsparcia zakupów maszyn rolniczych ukraińskiej produkcji. Jego celem jest osiagniecie przez lokalnych producentów (40 ukraińskich zakładów produkujących maszyny i urządzenia rolnicze, które mogą uczestniczyć w programie) $60 . \%$ udziału w rynku do 2020 r. W ramach programu przewidziano dotację w wysokości 20.\% kosztów inwestycji w maszyny rolnicze produkowane na Ukrainie. Z dotacji tych chętnie korzystano wyczerpując fundusze przewidziane na 2017 rok - w programie wzięło udział ponad 1220 gospodarstw (nabywając ponad 2,9 tys. maszyn rolniczych o wartości 134,1 mln hrywien). Przewidziany na 2018 rok budżet wynosił 1 mld hrywien. Na lata 2019-2020 planowano zwiększenie budżetu wskazanego programu do 1,5 mld hrywien (Duże..., 2018).

\section{Podsumowanie}

Sektor rolniczy Ukrainy pozostaje wiodącą branżą w kraju, określającą jego rozwój gospodarczy i zapewniającą bezpieczeństwo żywnościowe. Eksport ukraińskich produktów rolnych w okresie od stycznia do listopada 2017 r. wzrósł o 2,7 mld dolarów amerykańskich (19\%) w porównaniu z analogicznym okresem roku poprzedzającego $(16,4$ mld dolarów) (Rekordowe..., 2018).

Władze Ukrainy upatrują w sektorze rolnym, jego produkcji i eksporcie, potencjalną lokomotywę trwałego wzrostu gospodarczego. Wykorzystanie potencjału zależy jednak od, m.in., koniunktury na rynkach eksportowych, poprawy klimatu inwestycyjnego, poprawy kształtu polityki władz, w tym dotyczącej reformy rolnej. Wydaje się bowiem, że polityka państwa skupia się na zmianach ilościowych a nie jakościowych, umacniając rozwój dotychczasowego modelu koncentracji produkcji w ramach wielkich agroholdingów (Sarna, 2014).

Na Ukrainie, w wyniku nierównomiernego podziału zasobów inwestycyjnych, doszło do nieproporcjonalności w poziomie rozwoju gospodarki rolnej i innych branż gospodarki, na niekorzyść branży produkcji rolniczej (Sarna, 2014). Tymczasem inwestycje mają 
kluczowe znaczenie dla rozwoju sektora. Wpływają na procesy społeczno-ekonomiczne dzięki wywołanym przez nie efektom: ekonomicznym, zasobowym, technicznym, informacyjnym i socjalnym.

Efekt ekonomiczny inwestycji ukazuje się pod postacią wzrostu produkcji, polepszeniu jej jakości, obniżenia kosztu własnego produkcji i w konsekwencji zwiększenia dochodu. Skutki te wywołuje wprowadzenie nowej techniki i technologii oraz doskonalenie organizacji produkcji i pracy. Postęp naukowo-techniczny wyzwala w przedsiębiorstwie zasoby: materialne, finansowe i pracy. Osiaga się to dzięki automatyzacji produkcji i wprowadzeniu zasobo-oszczędnej techniki i technologii. Efekt techniczny natomiast wiąże się $\mathrm{z}$ pojawieniem się nowej techniki i technologii, wynalazków, racjonalizatorskich propozycji, know-how i innych innowacji. Efekt informacyjny wiąże się z możliwościami gromadzenia i wykorzystywania zasobów informacji w działalności produkcyjnej i administracyjnej dzięki rozwojowi technik elektronicznych i teleinformatycznych. Socjalny efekt inwestycji może mieć charakter zarówno pozytywny jak i negatywny. W wymiarze pozytywnym oznacza, miedzy innymi, podwyższenie poziomu życia ludności i pełniejsze zaspokojenie potrzeb oraz poprawę warunków pracy. Wymienione efekty są ściśle ze sobą powiązane oddziałując na siebie nawzajem (Gutkewicz, Sydorenko, 2016).

Ocena rozwoju sektora rolnego na Ukrainie, w ukraińskich pracach naukowych, nie jest jednoznaczna. Z perspektywy wskaźników statystycznych obserwuje się stabilny wzrost i pozytywną dynamikę rozwoju. Równocześnie jednak rozwój ten opiera się na ekstensywnych technologiach i w warunkach licznych barier rynkowych, w tym niedostatecznej jakości kapitału ludzkiego i słabej infrastruktury wiejskiej (Gutkewicz i Sydorenko, 2016).

Wśród podstawowych czynników nieskuteczności rozwoju sektora rolnospożywczego wskazuje się: wzrost znaczenia agroholdingów w sektorze rolnym w obwodach południowo-centralnej i wschodniej Ukrainy, dominowanie małych gospodarstw rolnych w zachodnich obwodach kraju a także pogłębiający się upadek infrastruktury rynku rolnego oraz zaniechanie gospodarki obszarów wiejskich. Skutkuje to nieefektywnym wykorzystaniem potencjału rolnictwa i przetwórstwa rolno-spożywczego w skali kraju. Ponadto, „wzmacniają one dalszą replikację powiązanych między sobą negatywnych zjawisk, np. pogłębiające się procesy monopolizacji, centralizacji oraz korupcji, które kompleksowo tworzą swoistą <<triadę zasadniczych problemów>> sektora rolnospożywczego Ukrainy" (Borshchevskiy, Krupin, Maksymenko, 2016).

Poprawa jakości produkcji, obniżenie jej kosztów, zwiększenie żyzności i wydajności gleb, zastosowanie nowoczesnych technologii, zwiększenie stopnia automatyzacji i mechanizacji produkcji może wspomóc konkurencyjność ukraińskiego rolnictwa na europejskich i światowych rynkach oraz zintensyfikować pozyskiwanie środków kapitałowych $z$ handlu międzynarodowego (Chomczuk, 2002).

\section{Literatura}

Borshchevskiy V., Krupin V., Maksymenko A., (2016). Rozwój i innowacje w sektorze rolno-spożywczym Ukrainy w świetle procesów transformacyjnych (Development and innovations in the agri-food sector of Ukraine in the light of transformation processes). PAN, 61-70. 


\section{E. Eyżwa}

Chomczuk T., (2002). Analiza komparatywna rolnictwa Ukrainy i Polski na tle państw Unii Europejskiej (Comparative analysis of agriculture in Ukraine and Poland against the background of European Union countries). Rocznik Akademii Rolniczej w Poznaniu, 343, 53-70.

Стратегія розвитку аграрного сектору економіки до 2020 року (Strategy for the development of the agricultural sector to 2020). (2013). Національна академія аграрних наук України, Київ.

Duże zainteresowanie programem zakupu maszyn rolniczych (Great interest in the farm machinery purchase program) (2018). Pobrano 14 grudnia $2018 \mathrm{z}$ http://www.farmer.pl/agroskop.

Grunty rolne nadal objete moratorium (Agricultural land still covered by the moratorium) (2017). Pobrano 26 listopada $2018 \mathrm{z}$ http://www.farmer.pl/agroskop.

Gutkewicz, S., Sydorenko, P. (2016). Problemy rozwoju rolniczo-przemysłowej Ukrainy (Problems of agricultural and industrial development of Ukraine). Zeszyty Naukowe PWSZ w Plocku, Nauki Ekonomiczne, 23, 406412 .

Parlament przedłużył moratorium na sprzedaż ziemi rolnej (Parliament extended the moratorium on the sale of agricultural land) (2017). Pobrano 26 listopada $2018 \mathrm{z} \mathrm{http://www.farmer.pl/fakty.}$

Pawljuk, I., (2017). Polskie znaczy dobre (Polish means good). Farmer, 6. Pobrano 10 listopada 2018 z http://www.farmer.pl/technika-rolnicza/maszyny-rolnicze/polskie-znaczy-dobre,72095.html

Powodzenie dotowanych zakupów sprzętu rolniczego (The success of subsidized purchases of agricultural equipment) (2018). Pobrano 20 listopada $2018 \mathrm{z} \mathrm{http://www.farmer.pl/agroskop.}$

Rekordowe wsparcie dla ukraińskiego kompleksu rolno-przemysłowego (Record support for the Ukrainian agroindustrial complex) (2018). Pobrano 22 listopada $2018 \mathrm{z} \mathrm{http://www.farmer.pl/agroskop.}$

Rocznik Statystyczny Rolnictwa (Statistical Yearbook of Agriculture). (2015). Główny Urząd Statystyczny, Warszawa.

Rząd ukraiński zatwierdził programy wsparcia rolnictwa w 2018 r. (The Ukrainian government approved agriculture support programs in 2018) (2018). Pobrano 25 listopada $2018 \mathrm{z} \mathrm{http://www.farmer.pl/finanse.}$

Sarna, A. (2014). Transformacja ukraińskiego rolnictwa: od kołchozów do agroholdingów (Transformation of Ukrainian agriculture: from collective farms to agroholding), Kmentarze, nr 127, Ośrodek Studiów Wschodnich, 1-10. Pobrane 10 grudnia 2018 z https://www.osw.waw.pl/.

Top 100 Latifundists Ukrainy, Latifundis.com https://atifundist.com/rating/top100\#.

Ukraina zainwestowała więcej w rolnictwo (Ukraine has invested more in agriculture). (2018). Pobrano 12 grudnia $2018 \mathrm{z} \mathrm{http://www.farmer.pl/agroskop.}$

\section{Do cytowania / For citation:}

Łyżwa E. (2019). Inwestycje jako determinanta rozwoju sektora rolnego na Ukrainie. Problemy Rolnictwa Światowego, 19(3), 67-74; DOI: 10.22630/PRS.2019.19.3.47

Łyżwa E. (2019). Investments as a Determinant of the Agricultural Sector Development in Ukraine (in Polish). Problems of World Agriculture, 19(3), 67-74; DOI: 10.22630/PRS.2019.19.3.47 